\title{
EFFECT OF BIOCHAR ADDITION ON SOIL PROPERTIES AND CARROT PRODUCTIVITY GROWN IN POLLUTED SOILS
}

\author{
Rehab H. Hegab ${ }^{1 *}$, Doaa Eissa ${ }^{2}$, Ahmed Abou-Shady ${ }^{2}$, Osama \\ Abdelmottaleb $^{2}$ \\ ${ }^{1}$ Department of Soil Fertility and Microbiology, Water Resources and \\ Desert Soils Division, Desert Research Center, El-Matareya, Cairo, \\ Egypt \\ ${ }^{2}$ Department of Soil Physics and Chemistry, Water Resources and \\ Desert Soils Division, Desert Research Center, El-Matareya, Cairo, \\ Egypt \\ *E-mail: drrehabhh@yahoo.com
}

\begin{abstract}
oil contamination with heavy metals has become apparent in many Egyptian areas such as El-Gabal
\end{abstract} El-Asfer and $10^{\text {th }}$ Ramadan areas, as a result to the reuse of contaminated water for irrigation as an alternative to freshwater irrigation in these areas. Biochar plays a major role to stabilize heavy metals contained in contaminated soils by reduction. The study aimed studied effect of biochar application rates $(0,15$, and 30 ton/feddan) on carrot production, nutrients content and heavy metals reduction using some of measurements to assess heavy metal accumulation as the bio-accumulation (BCF), and translocation factors (TF) to determine heavy metals in the studied soils. The obtained results showed that carrot yield production and macronutrients content (NPK) increased with elevating biochar and mineral fertilizers application rates. Heavy metals content in shoot and roots of carrot plant reduced with increasing application rates of biochar and highest rates of mineral fertilizers. The most effective treatment was 30 ton/feddan biochar with $41 \mathrm{~N}, 16.9 \mathrm{P}_{2} \mathrm{O}_{5}$ and $41.7 \mathrm{~K}_{2} \mathrm{O} \mathrm{kg} /$ feddan, which achieved the highest yield of 12.2 and 13.1 ton/feddan of carrot roots in El-Gabal ElAsfer and $10^{\text {th }}$ Ramadan soils, respectively, and also it was the highest reduction for heavy metals in comparison with the other studied treatments. Biochar application increased available nutrients (NPK) in both studied soils, and decreased availability of heavy metals in polluted soils. The highest values of BAF were found in the control treatment, while the lowest values appeared with the most effective 
treatment in the studied soils. The TF value for $\mathrm{Fe}$ and $\mathrm{Ni}$ was less than 1 , while for $\mathrm{Zn}, \mathrm{Pb}, \mathrm{Mn}, \mathrm{Co}, \mathrm{Cr}$, and $\mathrm{Cu}$, was higher than 1 .

Keywords: mineral fertilizer, biochar additives, bioaccumulation factor, translocation factor, heavy metals, carrot productivity, nutrients content

Annual air pollution arises from burring rice straw that is approximately 3.6 million tons in the open air. This resulted in sever risk to human health. Accordingly, rice straw should be recycled to useful materials such as biochar, that can be used in agriculture sector as soil amendment (AWRG, 2010). The Egyptian drainage wastewater is polluted with both organic and inorganic substances not suitable for direct application for irrigation. On the other hand, sewage sludge is highly contaminated with heavy metals, organic pollutants, and pathogens. The drainage wastewater is used now for irrigation. In El-Gabal El-Asfer area, the addition of sewage sludge is widely practiced. Also, the industrial activities resulted in dramatical contamination in $10^{\text {th }}$ Ramadan area (Rashed et al., 1995; AbdelShafy and Raouf, 2002 and Abou-Shady, 2016). In general, the bioavailability of heavy metal determines soil toxicity and its potential risk if it enters human food chain. Hang et al. (2016) reported that the concentration of heavy metals decreased yield in the sequence as leafy vegetables $>$ stalk vegetables/root vegetables/solanaceous vegetables $>$ legume vegetables/melon vegetables, the safe ranges of heavy metals for human health were $0.001-0.233 \mathrm{mg} / \mathrm{kg}$ for $\mathrm{Pb}, 0.005-0.023 \mathrm{mg} / \mathrm{kg}$ for $\mathrm{Cd}$, $0.011-0.227 \mathrm{mg} / \mathrm{kg}$ for $\mathrm{Cu}, 0.092-1.591 \mathrm{mg} / \mathrm{kg}$ for $\mathrm{Zn}$ and $0.030-0.188$ $\mathrm{mg} / \mathrm{kg}$ for As. Alghobar and Suresha (2016) reported that the growth and yield characters of rice crop were not improved by irrigation with untreated wastewater, however the high concentration of trace metals affected by lowering the growth and yield.

The biochar has a direct effect on the bioavailability of heavy metals containing polluted soils. The bioavailability of pollutants governs their ecotoxicology and degradation in contaminated soils (Zhang et al., 2013). Adding biochar to polluted soils is considered a modern technology to enhance remediation process. This may be due to the fact that biochar has the capability to reduce the available heavy metals in contaminated soils by several mechanisms such as adsorption, co-precipitation, and complexes reactions. Also, biochar can be used as amendment to improve soil fertility, water retention, and microbial activities that eventually improve plant productivity (Verheijen et al., 2010 and Montanarella and Lugato, 2013). $\mathrm{Naz}$ et al. (2015) stated that an increase in concentrations of heavy metals reduced the growth parameters and nutrient contents of plant.

Egyptian J. Desert Res., 66, No. 2, 327-350 (2016) 
Under the conditions of soils contaminated with heavy elements, the application of mineral fertilizers increased the heavy metals level in soil, while if applied with organic matter reduce this effect, where that increased the activity of factors, which reduce the level of heavy elements in these soils. Ramadan and Adam (2007) stated that the best treatments for yield of tomato keep far away from the range of toxic levels of heavy metal, were $25 \%$ chicken manure plus $75 \%$ mineral fertilizer then $75 \%$ chicken manure plus 25\% mineral fertilizer. Singh and Agrawal (2013) reported that the application of NPK fertilizer combination with FYM can be recommended as a cheap technique for reducing the availability of heavy metals in metal contaminated fields, which consequently, increase the activities of antioxidant enzymes and reduce photosynthetic rate, growth, and yield of the plants when NPK fertilizer applied alone. Yu-Kui et al. (2009) reported that nitrogen fertilization management is beneficial for reducing production costs, protecting the environment, and improving the quality of farm products. Beata and Cyraniak (2014) reported that the $\mathrm{N}$ fertilizer applied at range 40-200 kg N/ha resulted in an increased accumulation of $\mathrm{Cd}, \mathrm{Zn}$ and $\mathrm{Ni}$, but had no impact on the levels of $\mathrm{Pb}, \mathrm{Cd}$ and $\mathrm{Cu}$ in the yield of carrot. While, $\mathrm{K}$ fertilizer form as $\mathrm{K}_{2} \mathrm{SO}_{4}$ can reduce desorption of heavy metals (mainly $\mathrm{Cd}$ ) in the soil and thus reduce their accumulation in plants as compared to $\mathrm{KCl}$ fertilization. The main objective of study was to assess the application of biochar produced from rice straw for reducing heavy metals availability and content in carrot plant (Daucus carota).

\section{Soil Analysis}

\section{MATERIALS AND METHODS}

The soil samples were collected from two sites. In the first site, soils were collected from El-Gabal El-Asfer area within latitude $30^{\circ} 13^{\prime} 5^{\prime \prime} \mathrm{N}$ and longitude $31^{\circ} 21^{\prime} 32^{\prime \prime}$ E. The second soils were collected from $10^{\text {th }}$ Ramadan area within latitude $30^{\circ} 24^{\prime} 37^{\prime \prime} \mathrm{N}$ and longitude $31^{\circ} 50^{\prime} 4^{\prime \prime} \mathrm{E}$. the soil sample calculated at depth $0-30 \mathrm{~cm}$ for the two studied soils. The biochar additives were $0,1,3$, and $5 \%$ for columns experiment. Mineral fertilizers of nutrients (NPK) were added with the ratios of $0,50,75$, and $100 \%$, according to the sufficient levels for carrot requirements of nutrients doses during different stages of carrot growth simultaneously with biochar additives.

Soil characteristic including the physical and chemical properties for the up mentioned two soils were carried out according to the following methods:

Mechanical analysis was determined according to Piper (1950), total organic matter content was determined according to Walkley and Black, soil reaction $(\mathrm{pH})$ was determined electrometrically in soil suspension 1: 2.5 using bench Beckman Glass Electrode $\mathrm{pH}-$ Meter, total soluble salts were determined in soil extract 1: 2.5, total carbonates content were determined 
using Collin's Calcimeter, cation exchange capacity was determined according to Jackson (1973), total heavy metals were detected using the Ionic Coupled Argon Plasma according to Ure (1995) in which $1.0 \mathrm{~g}$ dry soil finely ground and moistened with distilled water and heated in $100 \mathrm{ml}$ Teflon beaker in the presence of $10 \mathrm{ml} \mathrm{HNO}_{3}$ and eventually evaporated to

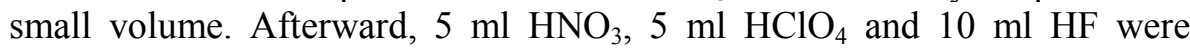
added and heated until fumes were produced. After $30 \mathrm{~min}$ of fuming, $10 \mathrm{ml}$ $\mathrm{HCl}(1 / 1, \mathrm{v} / \mathrm{v})$ was added and boiled for $10 \mathrm{~min}$. The final digest was cooled and diluted to $100 \mathrm{ml}$ using distilled water.

\section{Plant Analysis}

Plant samples including shoots and roots were thoroughly washed and dried at $70^{\circ} \mathrm{C}$. Plant samples were wet digested using $\mathrm{H}_{2} \mathrm{O}_{2}$ and $\mathrm{H}_{2} \mathrm{SO}_{4}$ according to procedure described by Nicholson (1984). Total heavy metals content were determined using Ionic Coupled Argon Plasma.

\section{Biochar Preparation}

Rice straw samples were collected from El-Sharkia Governorate, Egypt. Rice straw samples were oven dried at $105^{\circ} \mathrm{C}$ until constant weight were achieved, then ground to $<2 \mathrm{~mm}$ in diameter. Samples were placed into ceramic crucibles and well covered to provide oxygen limited condition during biochar production. The temperature was elevated to $400^{\circ} \mathrm{C}$ to ensure the pyrolysis using Muffle Furnace (NEY, M-525, Series II). Biochar was kept at room temperature prior to analysis. Biochar's $\mathrm{pH}$ and $\mathrm{EC}$ were determined after shaking suspension 1:10. Ash content was determined using a dry combustion method in which $5 \mathrm{~g}$ of biochar was heated at $500^{\circ} \mathrm{C}$ for 8 $\mathrm{h}$ (Song and Guo, 2012). The crucible was then cooled to room temperature and reweighted. The percentage of ash content was then calculated as follows:

Ash content $(\%)=$ weight of Ash $(\mathrm{g}) /$ weight of biochar $(\mathrm{g})$ X 100

The chemical activation processes were carried out to increase the total surface area of biochar that eventually became close to the commercial activated carbon. This was carried out via immersing biochar in $30 \%$ phosphoric acid overnight, and washing it five times using hot water $\left(90^{\circ} \mathrm{C}\right)$ until supernatant $\mathrm{pH}$ becames 7. Afterward, the biochar was kept dried overnight at $80^{\circ} \mathrm{C}$. The dried samples were preserved in desiccators to avoid further absorption of moisture. The scanning electron microscopy (SEM) was carried out on activated biochar at $400^{\circ} \mathrm{C}$, activated biochar at $300^{\circ} \mathrm{C}$, inactivated biochar samples, and commercially activate carbon using SEM Quanta FEG attached with EDX Unit, with accelerating voltage $30 \mathrm{k.v}$, (magnification 250x up to 200000061 nd resolution for Gun. $1 \mathrm{~m}$ ). 


\section{Soil Column Experiment}

The adsorption experiments were carried out in PVC column with an inside diameter $5 \mathrm{~cm}$ and $30 \mathrm{~cm}$ high. Fiber glasses were installed in the bottom of each column. The columns were prepared in order to obtain four levels of biochar in the El-Gabal El-Asfer soil. Soil alone $\left(\mathrm{B}_{0}\right)$, which was the control treatment and soil mixed with 1,3 and $5 \%$ of activated biochar at $400^{\circ} \mathrm{C}$, indicated $\mathrm{B}_{1}, \mathrm{~B}_{3}$ and $\mathrm{B}_{5}$, respectively. $100 \mathrm{mg} \mathrm{L}^{-1}$ of $\mathrm{Pb}^{2+}$ was added to each treatment. Soil field capacity was preserved wet and the outlet discharge was collected and re-added again. After 45 days, soil samples were air dried and the concentrations of available $\mathrm{Pb}^{2+}$ were determined.

\section{Pot Experiments}

This experiment was carried out at Desert Research Center. Two location contaminated with heavy metals organic pollutants, and pathogens, where El-Gabal El-Asfer soil irrigated by drainage wastewater and the $10^{\text {th }}$ Ramadan soil, contaminated with industrial activities. Bulk of soil samples was packed into pots $25 \mathrm{~cm}$ in diameter. A weight of $8 \mathrm{~kg}$ soil was transferred to each pot and treated with 0,15 and 30 ton/feddan inactivated biochar at $400^{\circ} \mathrm{C}$, with 3 replicates for each treatment. Five carrot seeds were planted in each pot and after germination decreased to 2 plants/pot (pot area $=0.0491 \mathrm{~m}^{2}$, Number of plants/feddan $=171210$ plants) and twelve treatments were evaluated. The experimental design was split plot in pots with three replications including 36 treatments for each soil type. Treatments were as following:

(T1) Without biochar and mineral fertilizer,

(T2) Without biochar and $50 \%$ of NPK/feddan,

(T3) Without biochar and $75 \%$ of NPK /feddan,

(T4) Without biochar and $100 \%$ NPK,

(T5) 15 ton/feddan of biochar without fertilizer,

(T6) 15 ton/feddan biochar with $50 \%$ of NPK/feddan,

(T7) 15 ton/feddan biochar with $75 \%$ of NPK/feddan,

(T8) 15 ton/feddan biochar with $100 \%$ of NPK/feddan,

(T9) 30 ton/feddan biochar without fertilizer,

(T10) 30 ton/feddan biochar with $50 \%$ of NPK/feddan,

(T11) 30 ton/feddan biochar with $75 \%$ of NPK/feddan,

(T12) 30 ton/feddan biochar with $100 \%$ of NPK/feddan

Regarding the NPK compound fertilizer, it was added with the following ratios; $0,50,75$, and $100 \%$ from the sufficient levels doses for carrot, $200 \mathrm{~kg}$ / feddan of ammonium sulfate $20.5 \%$ (41 kg N/ feddan), 250 $\mathrm{kg} /$ feddan of super phosphate $15.5 \%\left(16.9 \mathrm{~kg} \mathrm{P}_{2} \mathrm{O}_{5} /\right.$ feddan $)$, and $100 \mathrm{~kg}$ /feddan of potassium sulfate $50 \%\left(41.7 \mathrm{~kg} \mathrm{~K}_{2} \mathrm{O} /\right.$ feddan $)$. The biochar application rates for greenhouse pot experiments were 0,15 and 30 ton/ feddan. The $\mathrm{N}$ and $\mathrm{K}$ fertilizers were divided into two doses for two stages.

Egyptian J. Desert Res., 66, No. 2, 327-350 (2016) 
The first stage was added after one month from seeds germination and the second dose was added during the carrot heading stage, while phosphorus fertilizer was applied during bed preparation. The outlet leachate was collected and later re-added to the treated soils, to avoid heavy metals and nutrients leaching. Nitrogen, phosphorous, potassium and trace elements were determined according to Page et al. (1982) and Klute (1986).

The Biological Concentration Factor (BCF) was calculated as metal concentration ratio of plant roots to soil. Translocation Factor (TF) was described as ratio of heavy metals in plant shoot to that in plant root. Biological Accumulation Factor (BAF) was calculated as ratio of heavy metal in shoots to that in the soil (Biljana et al., 2015).

$\mathrm{BCF}=$ trace element concentration in plant roots / trace element concentration in soil

$\mathrm{TF}=$ heavy metal content in shoot / heavy metal content in root. The translocation factor (TF) reflects to the transference of heavy metals in plants (Zayed et al., 1998).

\section{Statistical Analysis}

The average and statistical package were calculated using Microsoft Excel. SPSS was used to calculate the analysis of covariance (ANCOVA). The significance level of the correlation test and regression analysis were set at $\alpha=0.05$.

\section{RESULTS AND DISCUSSION}

\section{Physical and Chemical Properties of the Studied Soils}

The soils collected from El-Gabal El-Asfer and $10^{\text {th }}$ Ramadan area are characterized by loamy sand texture as it mentioned in table (1). The total carbonate content was higher in El-Gabal El-Asfer soil (8.3\%) than the $10^{\text {th }}$ Ramadan soil $(2.1 \%)$. The same trend was observed with total organic matter and clay contents. This may resulted in increasing the cation exchange capacity for El-Gabal El-Asfer soil than $10^{\text {th }}$ Ramadan soil. The $\mathrm{pH}$ values were almost close to 7 for up mentioned soils. The electrical conductivity for the extractable soil past was $3.9 \mathrm{dS} \mathrm{m}^{-1}$ and $2.2 \mathrm{dS} \mathrm{m}^{-1}$ for El-Gabal El-Asfer and $10^{\text {th }}$ Ramadan soils, respectively. The total content and chemically exchangeable $\mathrm{Fe}, \mathrm{Mn}, \mathrm{Zn}, \mathrm{Cu}, \mathrm{Ni}, \mathrm{Pb}, \mathrm{Co}$, and $\mathrm{Cr}$ are listed in table (1). According to Ghorbani et al. (2002), the permission level of $\mathrm{Pb}^{2+}$ in El-Gabal El-Asfer soil exceeds the allowable limits. The total and chemically extractable $\mathrm{Pb}^{2+}$ was higher in El-Gabal El-Asfer soil than $10^{\text {th }}$ Ramadan soil. The same tendency was observed with the majority of heavy metals. 
Table (1). Some physical and chemical characteristics of El-Gabal El-Asfer and the $10^{\text {th }}$ Ramadan soils.

\begin{tabular}{|c|c|c|}
\hline & $\begin{array}{l}\text { El-Gabal El-Asfer } \\
\text { area }\end{array}$ & $10^{\text {th }}$ Ramadan area \\
\hline \multicolumn{3}{|c|}{ Partical size distribution \% } \\
\hline Sand $\%$ & 81.2 & 74.90 \\
\hline Silt \% & 7.6 & 6.24 \\
\hline Clay $\%$ & 11.3 & 18.82 \\
\hline Texture class & Loamy sand & Loamy sand \\
\hline $\mathrm{CaCO}_{3} \%$ & 8.30 & 2.13 \\
\hline OM \% & 4.31 & 0.12 \\
\hline CEC (me/100g) & 23.9 & 6.22 \\
\hline pH (1:2.5) & 7.72 & 7.20 \\
\hline $\mathrm{EC}(\mathrm{ds} / \mathrm{m})$ & 3.98 & 2.20 \\
\hline \multicolumn{3}{|c|}{$\begin{array}{l}\text { Total content of heavy metal } \\
\qquad(\mathrm{mg} / \mathrm{kg})\end{array}$} \\
\hline $\mathrm{Fe}$ & 8723 & 7981 \\
\hline $\mathrm{Mn}$ & 377 & 289.9 \\
\hline $\mathrm{Zn}$ & 245 & 223.9 \\
\hline $\mathrm{Cu}$ & 109 & 10.03 \\
\hline $\mathrm{Ni}$ & 57 & 20.10 \\
\hline $\mathrm{Pb}$ & $112^{*}$ & 75.90 \\
\hline $\mathrm{Co}$ & 7.98 & 6.71 \\
\hline $\mathrm{Cr}$ & 30.91 & 57.13 \\
\hline \multicolumn{3}{|c|}{$\begin{array}{l}\text { Chemically extractable } \\
\text { heavy metals (mg/kg) }\end{array}$} \\
\hline $\mathrm{Fe}$ & 39.7 & 31.9 \\
\hline $\mathrm{Mn}$ & 65.1 & 44.1 \\
\hline $\mathrm{Zn}$ & 27.1 & 5.60 \\
\hline $\mathrm{Cu}$ & 19.8 & 3.34 \\
\hline $\mathrm{Ni}$ & 7.96 & 3.90 \\
\hline $\mathrm{Pb}$ & 31.01 & 16.34 \\
\hline $\mathrm{Co}$ & 0.01 & 0.10 \\
\hline $\mathrm{Cr}$ & 6.87 & 11.55 \\
\hline
\end{tabular}

*This value is more than permissible limits for total $\mathrm{Pb}$ in soil; Adapted from Ghorbani et al. (2002). 


\section{Effect of Activation Process of Biochar on Some of their Chemical Properties}

Data in table (2) show that $\mathrm{pH}$ of activated biochar at 400 and $300^{\circ} \mathrm{C}$ is less than both of $\mathrm{pH}$ of commercially activate carbon and inactivated biochar at $400^{\circ} \mathrm{C}$, due to chemical activation process using phosphoric acid. The decrease in CEC of activated biochar at 400 and $300^{\circ} \mathrm{C}$ is due to increasing competition with hydrogen ions on cation exchange sites. $\mathrm{EC}$ of activated biochar at 400 and $300^{\circ} \mathrm{C}$ is a small value compared with inactivated biochar at $400^{\circ} \mathrm{C}$, due to the washing process during preparation. Fig. (1) shows the scanning electron microscopy images for biochar derived from rice straw at different temperatures compared with commercially activated carbon. It is clear seen that the surface structure of activated biochar formed at $400^{\circ} \mathrm{C}$ seems as crater-like compared with commercially activated carbon. It is confirmed that there is a larger numbers of the macropores of the activated biochar have been formed at $400^{\circ} \mathrm{C}$. In addition, a heterogenous range of structural features were observed in those samples. The commercial activated carbon was characterized by semi smooth surface. In contrast, biochar surfaces were characterized by granuler texture.

Regarded to available heavy metal in the El-Gabal El-Asfer soil, the increasing of biochar application rates decreased the available heavy metal in soils. This can interpreted due to heavy metal adsorpted on internal and external biochar surfaces. Table (3) shows that extractable $\mathrm{Pb}^{2+}$ from treated soils was significantly decreased when biochar amounts were increased. Some of other heavy metals in this study took the same trend of $\mathrm{Pb}^{2+}$. The above results agreed with obtained by Verheijen et al. (2010) and Montanarella and Lugato (2013).

Table (2). Some physicochemical properties of rice straw biochars.

\begin{tabular}{ccccc}
\hline & pH $(\mathbf{1 : 1 0})$ & $\mathbf{E C ~}(\mathbf{1 : 1 0})$ & Ash \% & CEC \\
\hline $\begin{array}{c}\text { Commercially } \\
\text { activate carbon }\end{array}$ & 4.60 & $1211 \mu \mathrm{s} / \mathrm{cm}$ & 10.68 & 19.10 \\
$\begin{array}{c}\text { Activated biochar } \\
\text { at } \mathbf{4 0 0}{ }^{\circ} \mathbf{C}\end{array}$ & 4.35 & $324 \mu \mathrm{s} / \mathrm{cm}$ & 15.10 & 5.96 \\
$\begin{array}{c}\text { Activated biochar } \\
\text { at } \mathbf{3 0 0}^{\circ} \mathbf{C}\end{array}$ & 4.85 & $407 \mu \mathrm{s} / \mathrm{cm}$ & 17.98 & 9.94 \\
$\begin{array}{c}\text { Inactivated biochar } \\
\text { at } \mathbf{4 0 0}^{\circ} \mathbf{C}\end{array}$ & 6.39 & $9230 \mu \mathrm{s} / \mathrm{cm}$ & 23.87 & 18.65 \\
\hline
\end{tabular}



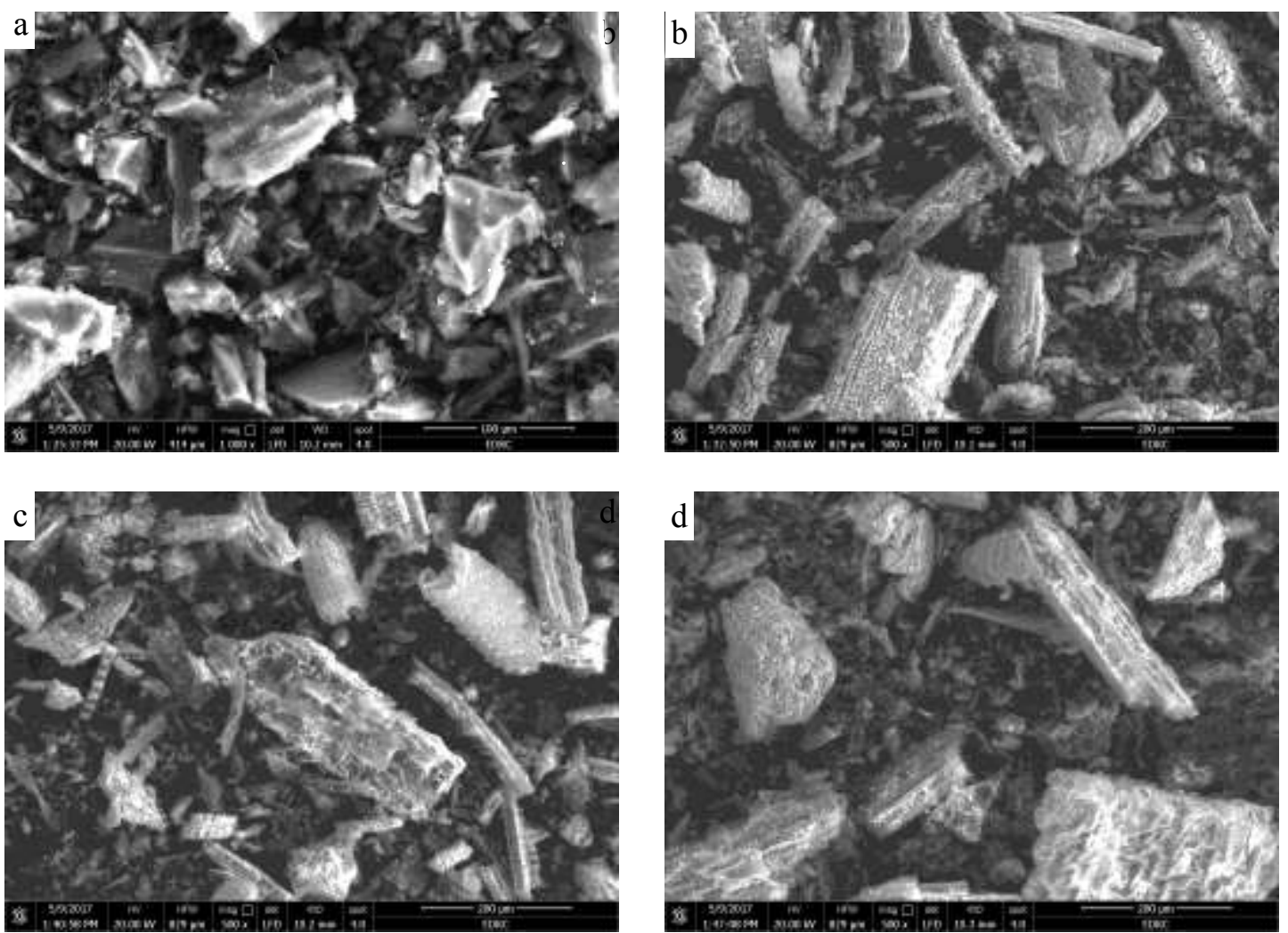

Fig. (1). Scanning electron micrographs (SEM) images of a. commercially activated carbon, b. activated biochar at $400^{\circ} \mathrm{C}$, c. activated biochar at $300^{\circ} \mathrm{C}$ and d. inactivated biochar at $400^{\circ} \mathrm{C}$.

Table (3). DTPA-extractable contents of $\mathrm{Pb}$ in the different soils column.

\begin{tabular}{cccc}
\hline $\begin{array}{c}\text { Rate of biochar } \\
\text { addition }\end{array}$ & $\begin{array}{c}\mathbf{p H} \\
(\mathbf{1 : 1 0})\end{array}$ & $\begin{array}{c}\mathbf{E C}(\boldsymbol{\mu} \mathbf{S} / \mathbf{c m}) \\
(\mathbf{1 : 1 0})\end{array}$ & $\begin{array}{c}\text { Pb available } \\
(\mathbf{p p m})\end{array}$ \\
\hline $\mathrm{B}_{0}$ & 6.99 & 128.4 & 41.0 \\
$\mathrm{~B}_{1}$ & 6.21 & 128.5 & 32.3 \\
$\mathrm{~B}_{3}$ & 6.15 & 130.2 & 27.8 \\
$\mathrm{~B}_{5}$ & 6.08 & 140.7 & 18.9 \\
\hline
\end{tabular}




\section{Effect of Biochar Application and Chemical Fertilizer on Available Nitrogen, Phosphorus, Potassium and Some Heavy Metals Contents of Polluted Soils}

Regarding soils macronutrients, data in table (4) assure that NPK fertilizers increase the availability of the those nutrients when compared with the control treatment. Biochar application for soils significantly increased the available nutrients in both soils. The best treatment was 30 ton/feddan biochar with $41 \mathrm{~N}, 16.9 \mathrm{P}_{2} \mathrm{O}_{5}$ and $41.7 \mathrm{~K}_{2} \mathrm{O} \mathrm{kg}$ /feddan. The amount of available nutrients increased with increasing rates of biochar and fertilizer application. The increase in available N, P and $\mathrm{K}$ in studied soil due to addition of biochar increase active capacity of surface area of studied soils and others nutrients released from biochar for soil. The above mentioned results are in agreement with those obtained by Lehmann et al. (2003), Liang et al. (2006), Solomon et al. (2007) and Abebe et al. (2012).

Table (4). Effect of biochar application and chemical fertilizer on available NPK (ppm) in of the El-Gabal El-Asfer and $10^{\text {th }}$ Ramadan areas soils.

\begin{tabular}{|c|c|c|c|c|c|c|c|}
\hline \multirow{3}{*}{$\begin{array}{c}\text { Biochar } \\
\%\end{array}$} & \multirow{3}{*}{$\begin{array}{c}\text { Fertilizers } \\
\%\end{array}$} & \multicolumn{3}{|c|}{ El-Gabal El-Asfer area } & \multicolumn{3}{|c|}{ The $10^{\text {th }}$ Ramadan area } \\
\hline & & $\mathbf{N}$ & $\mathbf{P}$ & $\mathbf{K}$ & $\mathbf{N}$ & $\mathbf{P}$ & $\mathbf{K}$ \\
\hline & & \multicolumn{6}{|c|}{$(\mathrm{mg} / \mathrm{kg})$} \\
\hline \multirow{4}{*}{ non } & non & 45.6 & 4.12 & 63.7 & 29.4 & 2.95 & 38.9 \\
\hline & 50 & 52.43 & 6.94 & 70.65 & 41.81 & 4.97 & 47.64 \\
\hline & 75 & 55.85 & 8.35 & 74.13 & 44.01 & 5.98 & 49.77 \\
\hline & 100 & 61.7 & 9.12 & 75.4 & 47.78 & 6.53 & 50.54 \\
\hline \multirow{4}{*}{15} & non & 49.3 & 5.13 & 69.4 & 39.79 & 3.67 & 46.88 \\
\hline & 50 & 57.6 & 7.88 & 77.6 & 45.14 & 5.64 & 51.89 \\
\hline & 75 & 62.4 & 9.32 & 84.3 & 48.23 & 6.67 & 55.98 \\
\hline & 100 & 67.3 & 10.31 & 89.7 & 51.39 & 7.38 & 59.28 \\
\hline \multirow{4}{*}{30} & non & 52.7 & 5.78 & 71.2 & 41.98 & 4.14 & 47.98 \\
\hline & 50 & 63.5 & 8.27 & 76.8 & 48.94 & 5.92 & 51.40 \\
\hline & 75 & 67.8 & 10.14 & 88.7 & 51.71 & 7.26 & 58.67 \\
\hline & 100 & 72.4 & 11.85 & 93.6 & 54.68 & 8.48 & 61.66 \\
\hline \multicolumn{2}{|c|}{ LSD $_{005}$ Biochar } & 0.28 & 0.08 & 0.32 & 0.23 & 0.06 & 0.22 \\
\hline \multicolumn{2}{|c|}{ LSD $_{0.05}$ Fertilizers } & 0.34 & 0.10 & 0.39 & 0.28 & 0.07 & 0.27 \\
\hline \multicolumn{2}{|c|}{$\mathrm{LSD}_{0.05}$ interaction } & 0.49 & 0.14 & 0.55 & 0.40 & 0.10 & 0.38 \\
\hline
\end{tabular}

Egyptian J. Desert Res., 66, No. 2, 327-350 (2016) 


\section{Effect of Biochar Application and Chemical Fertilizer on Carrot Yields in Polluted Soils}

Data in table (5) show that the yield parameters of carrot increased with increasing application of biochar and mineral NPK fertilizers in the two studied soils. The yields of carrot plants increased with increasing of biochar soil application rates when compared with control treatment. The treatments of 30 ton/feddan biochar with $41 \mathrm{~N}, 16.9 \mathrm{P}_{2} \mathrm{O}_{5}, 41.7 \mathrm{~K}_{2} \mathrm{O} \mathrm{kg} /$ feddan resulted in higher yields values than control treatment.

The most effective treatment recorded higher increases of yield parameters of carrot plant over control treatment by 54.3, 61.1, 58.6, 57.3, $61.3,59.8,57.3,61.5$ and $72.8 \%$ for weight of dry shoot $(\mathrm{g})$, dry root $(\mathrm{g})$, total dry plant (ton/feddan), fresh shoot $(\mathrm{g})$, fresh root $(\mathrm{g})$, total fresh plant (ton/feddan), fresh shoot (ton/feddan), fresh root (ton/feddan) and marketable (ton/feddan), respectively, in El-Gabal El-Asfer soil, while in the $10^{\text {th }}$ Ramadan, it achieved 47.0, 45.3, 45.6, 47.2, 57.4, 53.2, 47.3, 57.3 and $69.4 \%$, respectively. When comparing the two studied soil for yield production of carrot plant, under conditions of the most effective treatment, $10^{\text {th }}$ Ramadan soil recorded higher increases of yield parameters about 14.6, $17.1,16.5,9.4,7.2,8.1,9.9,6.9$ and $8.1 \%$ for weight of dry shoot $(\mathrm{g})$, dry root $(\mathrm{g})$, total dry plant (ton/feddan), fresh shoot $(\mathrm{g})$, fresh root $(\mathrm{g})$, total fresh plant (ton/feddan), fresh shoot (ton/feddan), fresh root (ton/feddan) and marketable (ton/feddan), respectively, than in El-Gabal El-Asfer soil. Increased pollution by heavy elements led to reduction in the productivity of carrot plant, whereas El-Gabal El-Asfer soil was the most polluted. This fact is due to the availability of heavy elements and soil salinity were greater than in $10^{\text {th }}$ Ramadan soil, and also due to the increase in cation exchange capacity and organic matter compared with $10^{\text {th }}$ Ramadan soil. The previous results assure that the efficiency and effectiveness of biochar application was the best in $10^{\text {th }}$ Ramadan soil than El-Gabal El-Asfer soil. This fact is in agreement with the conclusion given by Abebe et al. (2012) and Alghobar and Suresha (2016).

\section{Effect of Biochar Application and Chemical Fertilizer on Macronutrients and Heavy Metal Content in Shoot and Root of Carrot}

Data in tables (6 and 7) show that the average values of $\mathrm{N}, \mathrm{P}$, and $\mathrm{K}$ content in carrot shoot and root in the two studied soils increased with increasing biochar and fertilizer rates. The most effective treatment (30 ton/feddan biochar with $41 \mathrm{~N}, 16.9 \mathrm{P}_{2} \mathrm{O}_{5}$ and $41.7 \mathrm{~K}_{2} \mathrm{O} \mathrm{kg} /$ feddan) recorded significant increases of nutrients content in comparison with control treatment by $61.1,64.5,66.7,56.5,76.2$ and $62.7 \%$ for $\mathrm{N}, \mathrm{P}$ and $\mathrm{K}$ of shoot and root, respectively, in El-Gabal El-Asfer soil, while in $10^{\text {th }}$ Ramadan soil, it achieved $60.6,56.9,61.1,62.1,65.0$ and $65.8 \%$, respectively. Under conditions of the most effective treatment, the higher average values of $\mathrm{N}, \mathrm{P}$, 
and $\mathrm{K}$ content in shoot and root of carrot achieved in $10^{\text {th }}$ Ramadan soil than in El-Gabal El-Asfer soil of about 15.8, 5.2 , 16.7, 20.7, 17.0 and 29.4\% for $\mathrm{N}, \mathrm{P}$ and $\mathrm{K}$ of shoot and root, respectively. The previous results agreed with those obtained by Abebe et al. (2012). Application of rice straw biochar on polluted soils significantly increased the values of exchangeable bases. The highest values of exchangeable bases observed at biochar treated soils might be attributed to the presence of ash in the biochar, whereas the ash content immediately released of the occluded mineral nutrients like $\mathrm{Ca}, \mathrm{K}$ and $\mathrm{N}$ for crop use. The results of the present study also agree with those obtained by Lehmann et al. (2003), Rondon et al. (2007) and Chan et al. (2008).

Concerning the effect of biochar on heavy metal reduction, the heavy metal content in shoot and roots of carrot reduced with increasing biochar application rates (Tables 6 and 7). The most effective treatment (30 ton/feddan biochar with $41 \mathrm{~N}, 16.9 \mathrm{P}_{2} \mathrm{O}_{5}$ and $41.7 \mathrm{~K}_{2} \mathrm{O} \mathrm{kg} /$ feddan) achieved the highest significant reduction of heavy metal of shoot and roots when compared with the other treatments in the two studied soils. The superior treatment was higher increases of heavy metal reduction content than control treatment of about 30.9, 22.4, 54.3, 33.4, 56.7,43.4, 56.2, 40.6, 56.8, 54.4, 20.9, 39.7, 34.8, 46.6, 13 and 29.3\% for Fe, $\mathrm{Mn}, \mathrm{Zn}, \mathrm{Cu}, \mathrm{Ni}, \mathrm{Pb}$, Co and $\mathrm{Cr}$ in shoot and roots, respectively in El-Gabal El-Asfer soil, while it recorded 29.6, 20.3, 69.9, 31.9, 70.1, 26.2, 70, 45.2, 69.8, 58, 45.7, 49.2, 54.8, 55.8, 40.1 and $44.1 \%$ for $\mathrm{Fe}, \mathrm{Mn}, \mathrm{Zn}, \mathrm{Cu}, \mathrm{Ni}, \mathrm{Pb}, \mathrm{Co}$ and $\mathrm{Cr}$ in shoot and roots, respectively in $10^{\text {th }}$ Ramadan soil. The above results are due to the important role biochar application to reduce heavy metal in soil, which reflexed on heavy metal conent in shoot and roots of carrot plant. These facts assure by results obtained by Verheijen et al. (2010), Montanarella and Lugato (2013) and Naz et al. (2015).

Also, the macronutrients in mineral fertilizers are involved in reducing the level of heavy metals in the soil, this result was due to explanations of Yu-Kui et al. (2009), Singh and Agrawal (2013) and Beata and Cyraniak (2014). 
Table (5). Effect of biochar application and mineral fertilizers on yield parameters of carrot plant in El-Gabal El-Asfer and $10^{\text {th }}$ Ramadan areas soils.

\begin{tabular}{|c|c|c|c|c|c|c|c|c|c|c|}
\hline \multirow{3}{*}{ 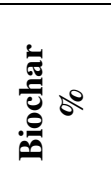 } & \multirow{3}{*}{ 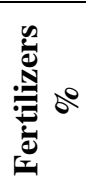 } & \multicolumn{3}{|c|}{ Dry weight } & \multicolumn{6}{|c|}{ Fresh weight } \\
\hline & & $\begin{array}{l}\text { Shoot } \\
\text { /plant }\end{array}$ & $\begin{array}{l}\text { Root } \\
\text { /plant }\end{array}$ & Total plant & $\begin{array}{l}\text { Shoot } \\
\text { /plant }\end{array}$ & $\begin{array}{l}\text { Root } \\
\text { /plant }\end{array}$ & $\begin{array}{l}\text { Total } \\
\text { plant }\end{array}$ & $\begin{array}{l}\text { Shoot } \\
\text { /fed }\end{array}$ & $\begin{array}{l}\text { Root } \\
\text { /fed }\end{array}$ & $\begin{array}{c}\text { Market } \\
\text { table }\end{array}$ \\
\hline & & \multicolumn{2}{|c|}{ (g) } & (ton/feddan) & \multicolumn{2}{|c|}{$(\mathrm{g})$} & \multicolumn{4}{|c|}{ (ton/feddan) } \\
\hline \multicolumn{11}{|c|}{ El-Gabal El-Asfer soil } \\
\hline \multirow{4}{*}{ non } & non & 5.9 & 7.9 & 2.35 & 20.5 & 27.5 & 8.2 & 3.5 & 4.7 & 3.1 \\
\hline & 50 & 7.7 & 11.9 & 3.35 & 27.0 & 41.5 & 11.7 & 4.6 & 7.1 & 5.3 \\
\hline & 75 & 11.0 & 14.1 & 4.30 & 38.3 & 49.5 & 15.0 & 6.6 & 8.5 & 6.7 \\
\hline & 100 & 11.0 & 17.2 & 4.83 & 42.5 & 60.3 & 17.6 & 7.3 & 10.3 & 8.5 \\
\hline \multirow{4}{*}{15} & non & 6.7 & 8.6 & 2.62 & 25.5 & 31.5 & 9.8 & 4.4 & 5.4 & 4.6 \\
\hline & 50 & 8.3 & 13.1 & 3.67 & 29.0 & 46.0 & 12.8 & 5.0 & 7.9 & 6.9 \\
\hline & 75 & 11.1 & 17.9 & 4.97 & 39.0 & 62.5 & 17.4 & 6.7 & 10.7 & 9.5 \\
\hline & 100 & 12.2 & 18.4 & 5.24 & 45.7 & 64.5 & 18.9 & 7.8 & 11.0 & 10.1 \\
\hline \multirow{4}{*}{30} & non & 7.3 & 9.4 & 2.86 & 29.5 & 37.5 & 11.5 & 5.1 & 6.4 & 5.7 \\
\hline & 50 & 10.2 & 14.0 & 4.14 & 35.7 & 49.0 & 14.5 & 6.1 & 8.4 & 7.7 \\
\hline & 75 & 12.6 & 20.1 & 5.60 & 44.0 & 70.5 & 19.6 & 7.5 & 12.1 & 11.2 \\
\hline & 100 & 12.9 & 20.3 & 5.68 & 48.0 & 71.0 & 20.4 & 8.2 & 12.2 & 11.4 \\
\hline \multicolumn{2}{|c|}{$\mathrm{LSD}_{005}$ Biochar } & 0.08 & 0.15 & 0.04 & 0.31 & 0.51 & 0.14 & 0.05 & 0.09 & 0.09 \\
\hline \multicolumn{2}{|c|}{$\mathrm{LSD}_{0.05}$ Fert. } & 0.10 & 0.19 & 0.05 & 0.38 & 0.62 & 0.17 & 0.06 & 0.11 & 0.11 \\
\hline \multicolumn{2}{|c|}{$\mathrm{LSD}_{0.05}$ Inter. } & 0.15 & 0.26 & 0.07 & 0.53 & 0.88 & 0.24 & 0.09 & 0.15 & 0.16 \\
\hline \multicolumn{11}{|c|}{$10^{\text {th }}$ Ramadan soil } \\
\hline \multirow{4}{*}{ non } & non & 8.0 & 13.4 & 3.7 & 28.0 & 32.6 & 10.4 & 4.8 & 5.6 & 3.8 \\
\hline & 50 & 8.9 & 16.7 & 4.4 & 31.0 & 48.5 & 13.6 & 5.3 & 8.3 & 6.4 \\
\hline & 75 & 9.9 & 19.9 & 5.1 & 34.5 & 59.5 & 16.1 & 5.9 & 10.2 & 8.4 \\
\hline & 100 & 12.3 & 20.3 & 5.6 & 43.0 & 67.4 & 18.9 & 7.4 & 11.5 & 9.7 \\
\hline \multirow{4}{*}{15} & non & 9.1 & 14.6 & 4.1 & 31.7 & 45.2 & 13.2 & 5.4 & 7.7 & 6.7 \\
\hline & 50 & 10.4 & 17.9 & 4.9 & 36.5 & 56.7 & 16.0 & 6.2 & 9.7 & 8.6 \\
\hline & 75 & 11.7 & 21.6 & 5.7 & 41.0 & 65.5 & 18.2 & 7.0 & 11.2 & 10.1 \\
\hline & 100 & 10.2 & 22.7 & 5.6 & 45.0 & 72.5 & 20.1 & 7.7 & 12.4 & 11.4 \\
\hline \multirow{4}{*}{30} & non & 9.9 & 15.9 & 4.4 & 34.6 & 51.2 & 14.7 & 5.9 & 8.8 & 7.8 \\
\hline & 50 & 11.8 & 18.6 & 5.2 & 38.0 & 63.9 & 17.4 & 6.5 & 10.9 & 10.2 \\
\hline & 75 & 14.3 & 23.7 & 6.5 & 49.0 & 71.7 & 20.7 & 8.4 & 12.3 & 11.5 \\
\hline & 100 & 15.1 & 24.5 & 6.8 & 53.0 & 76.5 & 22.2 & 9.1 & 13.1 & 12.4 \\
\hline \multirow{3}{*}{\multicolumn{2}{|c|}{$\begin{array}{l}\text { LSD }_{0.05} \text { Biochar } \\
\text { LSD }_{0.05} \text { Fert. } \\
\text { LSD }_{0.05} \text { Inter. }\end{array}$}} & 0.07 & 0.12 & 0.03 & 0.26 & 0.45 & 0.12 & 0.05 & 0.08 & 0.09 \\
\hline & & 0.09 & 0.15 & 0.04 & 0.32 & 0.55 & 0.15 & 0.06 & 0.09 & 0.10 \\
\hline & & 0.13 & 0.21 & 0.06 & 0.45 & 0.77 & 0.21 & 0.08 & 0.13 & 0.15 \\
\hline
\end{tabular}


Table (6). Effect of biochar application and chemical fertilizer on macronutrients and heavy metal content in shoot of carrot in the two studied soils.

\begin{tabular}{|c|c|c|c|c|c|c|c|c|c|c|c|c|}
\hline \multirow{4}{*}{ 戈 } & \multirow{4}{*}{ 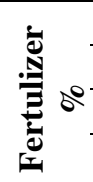 } & \multicolumn{11}{|c|}{ Macronutrients and heavy metal content in shoot } \\
\hline & & \multicolumn{3}{|c|}{ Macronutrients } & \multicolumn{8}{|c|}{ Heavy metal } \\
\hline & & $\mathbf{N}$ & $\mathbf{P}$ & $\mathbf{K}$ & Fe & Mn & Zn & $\mathbf{C u}$ & $\mathrm{Ni}$ & $\mathbf{P b}$ & Co & $\mathbf{C r}$ \\
\hline & & & $(\%)$ & & \multicolumn{8}{|c|}{ (mg/kg) } \\
\hline \multicolumn{13}{|c|}{ El-Gabal El-Asfer soil } \\
\hline \multirow{4}{*}{ non } & no & 0.93 & 0.05 & 0.93 & 20 & 45.3 & 33.7 & 12.50 & 2.65 & 1.53 & 0.69 & 1.85 \\
\hline & 50 & 1.16 & 0.08 & 1.97 & 19 & 43.6 & 32.4 & 12.03 & 2.55 & 1.51 & 0.68 & 1.83 \\
\hline & 75 & 1.59 & 0.12 & 2.51 & 19 & 42.5 & 31.6 & 11.73 & 2.49 & 1.50 & 0.66 & 1.81 \\
\hline & 10 & 1.77 & 0.15 & 3.26 & 18 & 41.3 & 30.7 & 11.40 & 2.42 & 1.48 & 0.65 & 1.8 \\
\hline \multirow{4}{*}{15} & no & 0.98 & 0.08 & 1.07 & 17 & 35.2 & 26.1 & 9.71 & 2.06 & 1.42 & 0.61 & 1.78 \\
\hline & 50 & 1.52 & 0.10 & 2.28 & 16 & 33.6 & 24.9 & 9.27 & 1.96 & 1.39 & 0.60 & 1.76 \\
\hline & 75 & 1.67 & 0.13 & 2.84 & 16 & 29.6 & 22.0 & 8.17 & 1.73 & 1.37 & 0.59 & 1.75 \\
\hline & 10 & 1.84 & 0.14 & 3.58 & 15 & 27.5 & 20.4 & 7.59 & 1.61 & 1.36 & 0.56 & 1.73 \\
\hline \multirow{4}{*}{30} & no & 1.03 & 0.10 & 1.12 & 15 & 24.1 & 17.9 & 6.66 & 1.41 & 1.28 & 0.53 & 1.68 \\
\hline & 50 & 1.54 & 0.12 & 2.42 & 14 & 22.4 & 16.7 & 6.19 & 1.31 & 1.25 & 0.52 & 1.67 \\
\hline & 75 & 1.91 & 0.14 & 3.33 & 14 & 20.6 & 15.3 & 5.68 & 1.21 & 1.23 & 0.48 & 1.64 \\
\hline & 10 & 2.39 & 0.15 & 3.91 & 14 & 19.8 & 14.7 & 5.47 & 1.16 & 1.21 & 0.45 & 1.61 \\
\hline \multirow{3}{*}{\multicolumn{2}{|c|}{$\begin{array}{l}\text { LSD }_{0.05} \text { Biochar } \\
\text { LSD }_{0.05} \text { Fert. } \\
\text { LSD }_{0.05} \text { Inter. }\end{array}$}} & 0.015 & 0.0011 & 0.035 & 0.8 & 0.32 & 0.24 & 0.090 & 0.019 & 0.004 & 0.0027 & 0.0027 \\
\hline & & 0.018 & 0.0013 & 0.043 & 0.9 & 0.40 & 0.30 & 0.110 & 0.023 & 0.005 & 0.0033 & 0.0033 \\
\hline & & 0.026 & 0.0019 & 0.060 & 1.3 & 0.56 & 0.42 & 0.155 & 0.033 & 0.007 & 0.0047 & 0.0046 \\
\hline \multicolumn{13}{|c|}{$\mathbf{1 0}^{\text {th }}$ Ramadan soil } \\
\hline \multirow{4}{*}{ non } & no & 1.12 & 0.07 & 1.65 & 16 & 40.9 & 30.4 & 11.29 & 2.39 & 1.38 & 0.62 & 1.67 \\
\hline & 50 & 1.37 & 0.09 & 2.58 & 16 & 38.1 & 28.3 & 10.51 & 2.23 & 1.32 & 0.60 & 1.60 \\
\hline & 75 & 1.51 & 0.14 & 3.48 & 15 & 37.9 & 28.1 & 10.45 & 2.21 & 1.34 & 0.59 & 1.61 \\
\hline & 10 & 1.70 & 0.15 & 4.06 & 15 & 34.8 & 25.9 & 9.61 & 2.04 & 1.25 & 0.55 & 1.52 \\
\hline \multirow{4}{*}{15} & no & 1.16 & 0.09 & 1.85 & 14 & 28.9 & 21.5 & 7.99 & 1.69 & 1.17 & 0.50 & 1.46 \\
\hline & 50 & 1.38 & 0.11 & 3.10 & 14 & 26.8 & 19.9 & 7.40 & 1.57 & 1.11 & 0.48 & 1.40 \\
\hline & 75 & 1.66 & 0.13 & 3.93 & 13 & 23.2 & 17.2 & 6.40 & 1.36 & 1.07 & 0.46 & 1.37 \\
\hline & 10 & 2.36 & 0.17 & 4.49 & 13 & 21.1 & 15.7 & 5.82 & 1.23 & 1.04 & 0.43 & 1.33 \\
\hline \multirow{4}{*}{30} & no & 1.23 & 0.11 & 1.97 & 12 & 18.4 & 13.7 & 5.08 & 1.08 & 0.98 & 0.40 & 1.28 \\
\hline & 50 & 1.49 & 0.13 & 3.35 & 12 & 16.7 & 12.4 & 4.61 & 0.98 & 0.93 & 0.38 & 1.24 \\
\hline & 75 & 1.75 & 0.15 & 4.16 & 12 & 15.6 & 11.6 & 4.30 & 0.91 & 0.93 & 0.37 & 1.24 \\
\hline & 10 & 2.84 & 0.18 & 4.71 & 11 & 12.3 & 9.1 & 3.39 & 0.72 & 0.75 & 0.28 & 1.00 \\
\hline \multirow{3}{*}{\multicolumn{2}{|c|}{$\begin{array}{l}\text { LSD }_{0.05} \text { Biochar } \\
\text { LSD }_{0.05} \text { Fert. } \\
\text { LSD }_{0.05} \text { Inter. }\end{array}$}} & 0.017 & 0.0012 & 0.036 & 0.6 & 0.34 & 0.25 & 0.094 & 0.020 & 0.007 & 0.0036 & 0.007 \\
\hline & & 0.021 & 0.0014 & 0.045 & 0.7 & 0.42 & 0.31 & 0.115 & 0.024 & 0.008 & 0.0044 & 0.008 \\
\hline & & 0.030 & 0.0020 & 0.063 & 1.0 & 0.59 & 0.44 & 0.162 & 0.034 & 0.012 & 0.0063 & 0.011 \\
\hline
\end{tabular}


Table (7). Effect of biochar application and chemical fertilizer on macronutrients and heavy metal content in roots of carrot in the two studied soils.

\begin{tabular}{|c|c|c|c|c|c|c|c|c|c|c|c|c|}
\hline \multirow{4}{*}{ 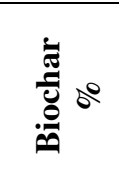 } & \multirow{4}{*}{ 密 } & \multicolumn{11}{|c|}{ Macronutrients and heavy metal content in roots } \\
\hline & & \multicolumn{3}{|c|}{ Macronutrients } & \multicolumn{8}{|c|}{$\begin{array}{l}\text { Heavy metal } \\
\end{array}$} \\
\hline & & $\mathbf{N}$ & $\mathbf{P}$ & $\mathbf{K}$ & $\mathbf{F e}$ & Mn & $\mathbf{Z n}$ & $\mathbf{C u}$ & $\mathbf{N i}$ & $\mathbf{P b}$ & Co & $\mathrm{Cr}$ \\
\hline & & & $(\%)$ & & \multicolumn{8}{|c|}{$(\mathbf{m g} / \mathbf{k g})$} \\
\hline \multicolumn{13}{|c|}{ El-Gabal El-Asfer soil } \\
\hline \multirow{4}{*}{ non } & non & 0.97 & 0.10 & 1.65 & 210 & 8.75 & 23.8 & 6.40 & 3.40 & 0.68 & 0.058 & 0.75 \\
\hline & 50 & 1.42 & 0.13 & 2.30 & 208 & 8.52 & 22.2 & 6.32 & 3.33 & 0.66 & 0.055 & 0.73 \\
\hline & 75 & 1.72 & 0.16 & 2.97 & 204 & 8.42 & 21.1 & 6.14 & 3.29 & 0.64 & 0.053 & 0.71 \\
\hline & 100 & 1.93 & 0.18 & 3.73 & 201 & 8.20 & 20.4 & 5.98 & 3.11 & 0.62 & 0.051 & 0.67 \\
\hline \multirow{4}{*}{15} & non & 1.05 & 0.11 & 1.77 & 193 & 7.80 & 17.5 & 5.73 & 2.96 & 0.56 & 0.048 & 0.66 \\
\hline & 50 & 1.66 & 0.14 & 2.55 & 187 & 7.65 & 17.2 & 5.44 & 2.65 & 0.53 & 0.045 & 0.65 \\
\hline & 75 & 1.79 & 0.17 & 3.38 & 185 & 7.37 & 16.5 & 5.18 & 2.32 & 0.51 & 0.044 & 0.63 \\
\hline & 100 & 1.97 & 0.21 & 3.99 & 177 & 6.93 & 16.1 & 4.88 & 2.21 & 0.49 & 0.041 & 0.61 \\
\hline \multirow{4}{*}{30} & non & 1.09 & 0.13 & 1.84 & 174 & 6.59 & 14.7 & 4.34 & 1.98 & 0.46 & 0.039 & 0.58 \\
\hline & 50 & 1.75 & 0.18 & 2.93 & 171 & 6.33 & 14.4 & 4.17 & 1.77 & 0.44 & 0.034 & 0.57 \\
\hline & 75 & 2.19 & 0.20 & 3.87 & 167 & 5.98 & 13.8 & 3.91 & 1.65 & 0.43 & 0.032 & 0.56 \\
\hline & 100 & 2.73 & 0.23 & 4.42 & 163 & 5.83 & 13.4 & 3.80 & 1.55 & 0.41 & 0.031 & 0.53 \\
\hline \multicolumn{2}{|c|}{ LSD $_{0.05}$ Biochar } & 0.01 & 0.00 & 0.03 & 0.57 & 0.03 & 0.12 & 0.03 & 0.024 & 0.003 & 0.0003 & 0.002 \\
\hline \multicolumn{2}{|c|}{ LSD $_{0.05}$ Fert. } & 0.02 & 0.00 & 0.04 & 0.70 & 0.04 & 0.15 & 0.04 & 0.029 & 0.004 & 0.0003 & 0.003 \\
\hline \multicolumn{2}{|c|}{$\mathrm{LSD}_{0.05}$ Inter. } & 0.03 & 0.00 & 0.05 & 0.98 & 0.06 & 0.21 & 0.05 & 0.041 & 0.005 & 0.0005 & 0.004 \\
\hline \multicolumn{13}{|c|}{$1^{\text {th }}$ Ramadan soil } \\
\hline \multirow{4}{*}{ non } & non & 1.24 & 0.11 & 2.14 & 177 & 7.90 & 21.4 & 5.78 & 3.07 & 0.61 & 0.052 & 0.68 \\
\hline & 50 & 1.38 & 0.14 & 3.55 & 174 & 7.84 & 19.8 & 5.54 & 2.94 & 0.58 & 0.048 & 0.65 \\
\hline & 75 & 1.77 & 0.18 & 3.91 & 172 & 7.81 & 19.6 & 5.23 & 2.87 & 0.54 & 0.046 & 0.62 \\
\hline & 100 & 2.40 & 0.21 & 4.55 & 167 & 7.73 & 19.3 & 5.12 & 2.67 & 0.51 & 0.044 & 0.61 \\
\hline \multirow{4}{*}{15} & non & 1.29 & 0.12 & 2.38 & 161 & 7.00 & 18.7 & 4.83 & 2.22 & 0.48 & 0.042 & 0.57 \\
\hline & 50 & 1.45 & 0.15 & 3.69 & 156 & 6.77 & 18.5 & 4.79 & 2.11 & 0.45 & 0.037 & 0.55 \\
\hline & 75 & 1.87 & 0.19 & 4.43 & 153 & 6.48 & 18.2 & 4.48 & 1.97 & 0.44 & 0.035 & 0.53 \\
\hline & 100 & 2.65 & 0.23 & 5.25 & 151 & 6.18 & 17.6 & 4.20 & 1.83 & 0.42 & 0.033 & 0.51 \\
\hline \multirow{4}{*}{30} & non & 1.35 & 0.14 & 2.54 & 147 & 5.86 & 16.7 & 3.60 & 1.54 & 0.38 & 0.031 & 0.45 \\
\hline & 50 & 1.52 & 0.19 & 4.11 & 146 & 5.67 & 16.4 & 3.36 & 1.43 & 0.35 & 0.029 & 0.43 \\
\hline & 75 & 2.59 & 0.24 & 5.45 & 143 & 5.51 & 16.2 & 3.29 & 1.37 & 0.33 & 0.026 & 0.41 \\
\hline & 100 & 2.88 & 0.29 & 6.26 & 141 & 5.38 & 15.8 & 3.17 & 1.29 & 0.31 & 0.023 & 0.38 \\
\hline \multirow{3}{*}{\multicolumn{2}{|c|}{$\begin{array}{l}\text { LSD }_{0.05} \text { Biochar } \\
\text { LSD }_{0.05} \text { Fert. } \\
\text { LSD }_{0.05} \text { Inter. }\end{array}$}} & 0.02 & 0.00 & 0.04 & 0.43 & 0.03 & 0.06 & 0.03 & 0.022 & 0.003 & 0.0003 & 0.003 \\
\hline & & 0.02 & 0.00 & 0.05 & 0.53 & 0.04 & 0.07 & 0.03 & 0.027 & 0.004 & 0.0003 & 0.004 \\
\hline & & 0.03 & 0.00 & 0.07 & 0.75 & 0.05 & 0.10 & 0.05 & 0.039 & 0.005 & 0.0005 & 0.005 \\
\hline
\end{tabular}

\section{Correlation}

To substantiate the relationship among biochar addition, soil types and fertilizers that possibly control growth of carrot, correlation coefficients were computed as shown in table (8). The obtained coefficients indicate that biochar is significant positively correlated with $\mathrm{K}$ in soil $(\mathrm{r}=0.560), \mathrm{P}$ in shoot $(r=0.605)$ and $P$ in root $(r=0.523)$ and significant positively correlated with fresh weight for shoot $(r=0.406)$, dry weight for shoot $(r=$ 
$0.406), \mathrm{N}$ in soil $(\mathrm{r}=0.506), \mathrm{P}$ in soil $(\mathrm{r}=0.464), \mathrm{N}$ in shoot $(\mathrm{r}=0.457)$ and $\mathrm{N}$ in root $(\mathrm{r}=0.457)$. And soil types is highly significant negatively correlated with $\mathrm{K}$ in root $(\mathrm{r}=0.566)$ and significant negatively correlated with fresh weight for root $(r=-0.488)$, dry weight for root $(r=-0.403)$ and significant positively correlated with $\mathrm{P}$ in soil $(\mathrm{r}=0.506)$. And fertilizers are highly significant positively correlated with all measured parameters under investigation.

Table (8). Correlation between biochar and chemical fertilizer on fresh and dry matter, N, P and $\mathrm{K}$ of carrot in two polluted soils.

\begin{tabular}{ccccccc}
\hline & \multicolumn{2}{c}{ Biochar } & \multicolumn{2}{c}{ Soil types } & \multicolumn{2}{c}{ fertilizers } \\
\cline { 2 - 7 } & Spearman & Sign. & Spearman & Sign. & Spearman & Sign. \\
\hline Fresh & $0.406^{*}$ & 0.049 & - & - & $0.856^{* * *}$ & 0.000 \\
Fresh & - & - & $-0.488^{*}$ & 0.016 & $0.786^{* *}$ & 0.000 \\
Fresh & - & - & - & - & $0.816^{* * *}$ & 0.000 \\
Dry & $0.406^{*}$ & 0.049 & - & - & $0.854^{* * *}$ & 0.000 \\
Dry & - & - & $-0.403^{*}$ & 0.051 & $0.786^{* *}$ & 0.000 \\
Dry & - & - & - & - & $0.816^{* * *}$ & 0.000 \\
N soil & $0.506^{*}$ & 0.012 & - & - & $0.769^{* *}$ & 0.000 \\
P soil & $0.464^{*}$ & 0.022 & $0.506^{*}$ & 0.012 & $0.657^{* * *}$ & 0.000 \\
K soil & $0.560^{* *}$ & 0.004 & - & - & $0.770^{* *}$ & 0.000 \\
N & $0.457^{* *}$ & 0.025 & - & - & $0.791^{* *}$ & 0.000 \\
N root & $0.457^{* *}$ & 0.025 & - & - & $0.845^{* *}$ & 0.000 \\
P & $0.605^{* *}$ & 0.002 & - & - & $0.743^{* *}$ & 0.000 \\
P root & $0.523^{* *}$ & 0.009 & - & - & $0.808^{* *}$ & 0.000 \\
K & - & - & - & - & $0.867^{* * *}$ & 0.000 \\
K root & - & - & $-0.566^{* *}$ & 0.004 & $0.705^{* *}$ & 0.000 \\
\hline
\end{tabular}

** significant at $\mathrm{p}=0.05 ;{ }^{*}$ significant at $\mathrm{p}=0.01$ and - is not significant.

To substantiate the relationship between biochar addition and some heavy metals content in shoots and roots of carrot, correlation coefficients were computed. Table (9) show that the obtained coefficients indicate that biochar is significant negatively correlated with $\mathrm{Fe}$ root $(\mathrm{r}=-0.524), \mathrm{Mn}$ shoot $(\mathrm{r}=-0.590), \mathrm{Mn} \operatorname{root}(\mathrm{r}=--0.757), \mathrm{Cu} \operatorname{shoot}(\mathrm{r}=-0.546), \mathrm{Cu} \operatorname{root}(\mathrm{r}=$ -0.583), Co shoot $(r=-0.656)$, Co root $(r=-0.734)$, Cr shoot $(r=-0.715), \mathrm{Cr}$ root $(r=-0.745)$, Ni shoot $(r=-0.535)$, Ni root $(r=-0.616), P b$ shoot $(r=-$ $0.689)$ and $\mathrm{Pb}$ root $(\mathrm{r}=-0.539)$ and significant negatively correlated with $\mathrm{Fe}$ shoot $(\mathrm{r}=-0.487)$ and $\mathrm{Zn}$ shoot $(\mathrm{r}=-0.501)$.

The effect of interaction between biochar, soil type and chemical fertilizer on growth of carrot was illustrated from statistical analysis, the Egyptian J. Desert Res., 66, No. 2, 327-350 (2016) 
coefficient of determination $\left(\mathrm{R}^{2}\right)$ of $\mathrm{Pb}$ and $\mathrm{Co}$ in shoot and $\mathrm{Zn}, \mathrm{Cu}$ and Ni in root is $0.807,0.922,0.735,0.658$ and 0.726 , respectively (Table 10 ). The coefficient of determination of $\mathrm{Mn}$ in shoot was $\mathrm{R}^{2}=0.768$, this means that $76.8 \%$ of the variance in $\mathrm{Mn}$ in shoot can be explained by the changes in interaction between soil and fertilizer. The remaining $23.2 \%$ of the variation of $\mathrm{Mn}$ in shoot was due to random variability. It was clear that the concentration of $\mathrm{Pb}^{2+}$ in shoots and roots were significantly decreased with increasing the application rates of biochar for the treated soils (Fig. 2).

Table (9). Correlation between biochar and chemical fertilizers on some heavy metals content shoots and roots of carrot.

\begin{tabular}{ccccccc}
\hline Metals & \multicolumn{2}{c}{ Biochar } & \multicolumn{2}{c}{ Soil types } & \multicolumn{2}{c}{ fertilizers } \\
\hline & Spearman & Sign. & Spearman & Sign. & Spearman & Sign. \\
\hline $\mathrm{Fe}$ & $-0.487^{*}$ & 0.016 & - & - & - & - \\
$\mathrm{Fe} \mathrm{root}$ & $-0.524^{* *}$ & 0.009 & - & - & - & - \\
$\mathrm{Mn}$ & $-0.590^{* * *}$ & 0.002 & - & - & - & - \\
$\mathrm{Mn}$ & $-0.757^{* *}$ & 0.000 & - & - & & \\
$\mathrm{Zn}$ & $-0.501^{*}$ & 0.013 & - & - & - & - \\
$\mathrm{Cu}$ & $-0.546^{* * *}$ & 0.060 & - & - & - & - \\
$\mathrm{Cu}$ root & $-0.583^{* *}$ & 0.003 & - & - & - & - \\
$\mathrm{Co}$ & $-0.656^{* *}$ & 0.000 & - & - & - & - \\
$\mathrm{Co} \mathrm{root}$ & $-0.734^{* *}$ & 0.000 & - & - & - & - \\
$\mathrm{Cr}$ & $-0.715^{* * *}$ & 0.000 & - & - & - & - \\
$\mathrm{Cr}$ root & $-0.745^{* * *}$ & 0.000 & - & - & - & - \\
$\mathrm{Ni}$ & $-0.535^{* * *}$ & 0.007 & - & - & $-0.431^{*}$ & 0.096 \\
$\mathrm{Ni}$ root & $-0.616^{* * *}$ & 0.001 & - & - & - & - \\
$\mathrm{Pb}$ & $-0.689^{* *}$ & 0.000 & - & - & - & - \\
$\mathrm{Pb}$ root & $-0.539^{* * *}$ & 0.007 & - & - & - & - \\
\hline
\end{tabular}

** significant at $\mathrm{p}=0.05 ;{ }^{*}$ significant at $\mathrm{p}=0.01$ and - is not significant.

Table (10). Effect of interaction between biochar, soil type and chemical fertilizer on heavy metals in carrot.

\begin{tabular}{ccccccc}
\hline & Mn & Zn & Cu & Ni & Pb & Co \\
\hline Biochar & - & 0.002 & - & - & - & 0.030 \\
Soil & - & - & - & - & - & - \\
Fertilizer & - & - & - & - & - & 0.029 \\
Bio. $x$ soil & - & 0.004 & - & - & - & 0.010 \\
Bio. $\chi$ Fer. & - & - & - & 0.040 & 0.010 & 0.006 \\
Soil $\chi$ Fer. & 0.020 & - & 0.040 & - & - & 0.003 \\
Bio. soil $\times$ Fer. & - & - & - & - & - & 0.002 \\
R $^{2}$ & 0.768 & 0.735 & 0.658 & 0.726 & 0.807 & 0.922 \\
\hline
\end{tabular}



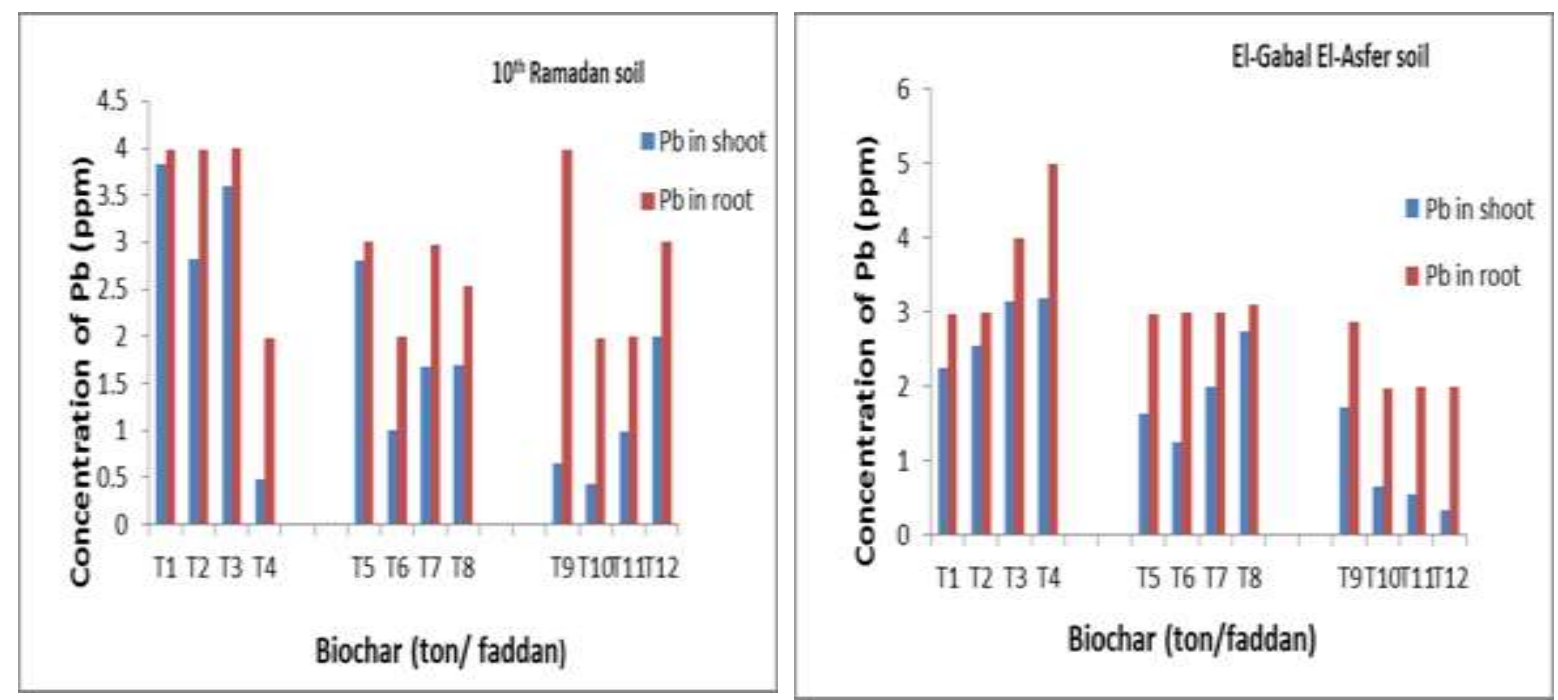

Fig. (2). Effect of biochar on $\mathrm{Pb}$ content in shoot and root of carrot in two polluted soil.

\section{Bioaccumulation Factor (BAF) and Translocation Factor (TF) of Heavy Metals in Polluted Soils}

Data in table (11) show that the BAF reflects the capacity of plant roots to adsorb heavy metals from polluted soils. The lowest values of BAF were observed in root for some heavy metals, when biochar was added at 30 ton/feddan. This is possibly due to the capacity of biochar to prevent absorption of some heavy metal when carrot was grown in heavy metals containing polluted soils. The biological translocation factor (TF) reflects to the transference of heavy metals in plants in vivo. In general, if TF is higher than 1 , the plant will accumulate heavy metals, however the lower values less than 1 indicates preventing heavy metals uptake (Olowoyo et al., 2010), also the TF for Fe was less than 1, and the same trend was observed with Ni. The TF values trended to oscillate with $\mathrm{Zn}, \mathrm{Pb}, \mathrm{Mn}, \mathrm{Co}, \mathrm{Cr}$ and $\mathrm{Cu}$, where TF values were higher than 1 (Table 12). The above results agreed with that obtained by Zayed et al. (1998) and Biljana et al. (2015). 
Table (11). Bio-Accumulation Factor (BAF) of heavy metals in carrot plant in the two polluted soils.

\begin{tabular}{|c|c|c|c|c|c|c|c|c|c|c|}
\hline \multirow{2}{*}{ 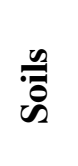 } & & & $\mathbf{F e}$ & Mn & $\mathbf{Z n}$ & $\mathbf{C u}$ & $\mathbf{N i}$ & $\mathbf{P b}$ & Co & $\mathbf{C r}$ \\
\hline & & & \multicolumn{8}{|c|}{ Bio Accumulation Factor (BAF) } \\
\hline \multirow{12}{*}{ 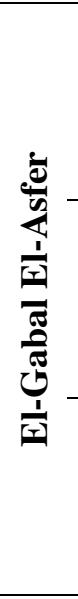 } & \multirow{4}{*}{ non } & non & 0.0241 & 0.0232 & & & & 0.0061 & 0.0073 & $0.02-10$ \\
\hline & & 50 & 0.0238 & 0.0226 & 0.0906 & 0.0579 & & 0.0059 & 0.0069 & 0.0238 \\
\hline & & 70 & 0.0234 & 0.0223 & 0.0862 & 0.0564 & 0.0577 & 0.0057 & 0.0067 & 0.0231 \\
\hline & & 100 & 0.0230 & 0.0217 & 0.08 & 0.05 & 0.05 & 0.0 & 0.0064 & 0.0218 \\
\hline & \multirow{4}{*}{15} & non & 0.0221 & 0.0207 & 0.0712 & 0.0526 & 0.0520 & 0.00 & 0.0060 & 0.0213 \\
\hline & & 50 & 0.0214 & 0.0203 & 0.07 & & & & 0.0056 & \\
\hline & & 70 & 0.0212 & 0.0196 & 0.06 & 0.04 & 0.04 & 0.00 & 0.00 & 0.0205 \\
\hline & & 100 & 0.0203 & 0.01 & 0.0658 & 0.0 & 0.038 & 0.0 & 0.0052 & 0.0198 \\
\hline & \multirow{4}{*}{30} & non & 0.0199 & 0.0175 & 0.0598 & 0.0 & 0.03 & 0.0 & 0.0049 & 188 \\
\hline & & 50 & 0.0196 & 0.0168 & 0.05 & 0.03 & 0.03 & 0.0 & 0.0043 & 0.0184 \\
\hline & & 70 & 0.0191 & 0.0159 & 0.056 & 0.035 & 0.025 & 0.00 & 0.0040 & 0.0183 \\
\hline & & 100 & 0.0187 & 0.0155 & 0.05 & 0.0349 & & & 0.0039 & 0.0171 \\
\hline \multirow{12}{*}{ 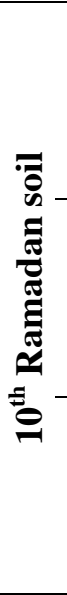 } & & non & 0.0221 & 0.0273 & 0.09 & & & & 0.0078 & 0.0119 \\
\hline & & 50 & 0.0218 & 0.0270 & 0.0 & & 0.14 & 0.00 & 0.0071 & 0.0115 \\
\hline & & 70 & 0.0215 & 0.0270 & 0.0875 & 0.5219 & 0.1430 & 0.0071 & 0.0069 & 0.0111 \\
\hline & & 100 & 0.0210 & 0.0267 & 0.0860 & 0.5105 & 0.1329 & 0.0067 & 0.0065 & 0.0107 \\
\hline & \multirow{4}{*}{15} & non & 0.0202 & 0.0241 & 0.0836 & 0.4820 & 0.1103 & 0.0063 & 0.0063 & 0.0100 \\
\hline & & 50 & 0.0196 & 0.0233 & 0.0827 & 0.4772 & 0.1050 & 0.0060 & 0.0056 & 0.0096 \\
\hline & & 70 & 0.0191 & & & & & & 0.0052 & 0.0092 \\
\hline & & 100 & 0.0190 & 0.0213 & 0.0787 & 0.4186 & 0.0908 & 0.0055 & 0.0049 & 0.0090 \\
\hline & \multirow{4}{*}{30} & non & 0.0184 & 0.0202 & 0.0746 & 0.3590 & 0.0765 & 0.0051 & 0.0046 & 0.0079 \\
\hline & & 50 & 0.0183 & 0.0196 & 0.0731 & 0.3349 & 0.0709 & 0.0047 & 0.0044 & 0.0075 \\
\hline & & 70 & 0.0179 & 0.0190 & 0.0723 & 0.3281 & 0.0682 & 0.0044 & 0.0039 & 0.0072 \\
\hline & & 100 & 0.0177 & 0.0185 & 0.0707 & 0.3164 & 0.0643 & 0.0041 & 0.0035 & 0.0067 \\
\hline
\end{tabular}

Bio accumulation factor (BAF) of heavy metals in carrot plant 
Table (12). Translocation Factor (TF) of heavy metals in roots of carrot grown in the two polluted soils.

\begin{tabular}{|c|c|c|c|c|c|c|c|c|c|c|}
\hline \multirow{2}{*}{$\frac{n}{\ddot{B}}$} & & & $\mathbf{F e}$ & Mn & $\mathbf{Z n}$ & $\mathbf{C u}$ & $\mathbf{N i}$ & $\mathbf{P b}$ & Co & $\mathrm{Cr}$ \\
\hline & 象 & 离 & \multicolumn{8}{|c|}{ Translocation Factor (TF) } \\
\hline \multirow{12}{*}{ 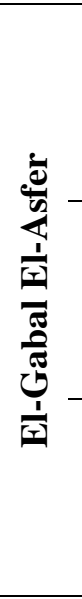 } & \multirow{4}{*}{ non } & non & 0.97 & 5.18 & 1.42 & 1.95 & 0.78 & 2.25 & 11.90 & 2.47 \\
\hline & & 50 & 0.95 & 5.12 & 1.46 & 1.90 & 0.77 & 2.30 & 12.33 & 2.49 \\
\hline & & 70 & 0.93 & 5.05 & 1.49 & 1.91 & 0.76 & 2.36 & 12.51 & 2.54 \\
\hline & & 100 & 0.94 & 5.04 & 1.51 & 1.90 & 0.78 & 2.40 & 12.65 & 2.67 \\
\hline & \multirow{4}{*}{15} & non & 0.89 & 4.51 & 1.50 & 1.69 & 0.69 & 2.52 & 12.92 & 2.71 \\
\hline & & 50 & 0.90 & 4.39 & 1.45 & 1.70 & 0.74 & 2.64 & 13.26 & 2.72 \\
\hline & & 70 & 0.90 & 4.02 & 1.33 & 1.58 & 0.75 & 2.68 & 13.38 & 2.76 \\
\hline & & 100 & 0.90 & 3.97 & 1.27 & 1.55 & 0.73 & 2.80 & 13.68 & 2.83 \\
\hline & \multirow{4}{*}{30} & non & 0.87 & 3.67 & 1.22 & 1.53 & 0.71 & 2.80 & 13.38 & 2.89 \\
\hline & & 50 & 0.85 & 3.54 & 1.16 & 1.48 & 0.74 & 2.87 & 15.04 & 2.94 \\
\hline & & 70 & 0.86 & 3.45 & 1.11 & 1.45 & 0.73 & 2.89 & 15.03 & 2.90 \\
\hline & & 100 & 0.87 & 3.40 & 1.10 & 1.44 & 0.75 & 2.94 & 14.30 & 3.05 \\
\hline \multirow{12}{*}{ 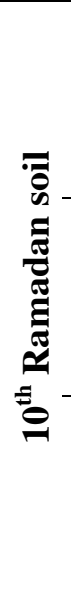 } & \multirow{4}{*}{ non } & non & 0.96 & 5.18 & 1.42 & 1.95 & 0.78 & 2.25 & 11.90 & 2.47 \\
\hline & & 50 & 0.92 & 4.86 & 1.43 & 1.90 & 0.76 & 2.27 & 12.53 & 2.43 \\
\hline & & 70 & 0.92 & 4.85 & 1.44 & 2.00 & 0.77 & 2.48 & 12.88 & 2.53 \\
\hline & & 100 & 0.93 & 4.51 & 1.34 & 1.88 & 0.76 & 2.44 & 12.51 & 2.49 \\
\hline & \multirow{4}{*}{15} & non & 0.91 & 4.14 & 1.15 & 1.65 & 0.76 & 2.46 & 11.90 & 2.57 \\
\hline & & 50 & 0.91 & 3.96 & 1.08 & 1.55 & 0.74 & 2.45 & 12.74 & 2.57 \\
\hline & & 70 & 0.91 & 3.58 & 0.95 & 1.43 & 0.69 & 2.45 & 13.20 & 2.61 \\
\hline & & 100 & 0.89 & 3.42 & 0.89 & 1.39 & 0.68 & 2.51 & 13.25 & 2.60 \\
\hline & \multirow{4}{*}{30} & non & 0.87 & 3.14 & 0.82 & 1.41 & 0.70 & 2.54 & 12.92 & 2.83 \\
\hline & & 50 & 0.86 & 2.94 & 0.76 & 1.37 & 0.69 & 2.63 & 13.11 & 2.88 \\
\hline & & 70 & 0.85 & 2.83 & 0.72 & 1.31 & 0.67 & 2.79 & 14.20 & 3.00 \\
\hline & & 100 & 0.84 & 2.29 & 0.58 & 1.07 & 0.56 & 2.39 & 11.90 & 2.59 \\
\hline
\end{tabular}

Translocation factor (TF) of heavy metals in roots

\section{CONCLUSION}

In the present study, the yield parameters and nutrients (NPK) content of carrot increased with elevating rates of biochar and mineral fertilizers application. Heavy metals were reduced by increasing application rates of biochar and highest rates of mineral fertilizers. The most effective treatment

Egyptian J. Desert Res., 66, No. 2, 327-350 (2016) 
was $\left(30\right.$ ton/feddan biochar with $41 \mathrm{~N}, 16.9 \mathrm{P}_{2} \mathrm{O}_{5}$ and $41.7 \mathrm{~K}_{2} \mathrm{O} \mathrm{kg}$ /feddan, which achieved the highest yield of 12.2 and 13.1 ton/feddan of carrot roots in El-Gabal El-Asfer and $10^{\text {th }}$ Ramadan soil, respectively, and also it was the highest reduction for heavy metals by comparison with the other studied treatments. Biochar application increased available nutrients (NPK) in both studied soils, and decreased availability of heavy metals in containing polluted soils. The highest values of BAF were found in control treatment while, the lowest values appeared with the most effective treatment. The TF value for $\mathrm{Fe}$ and $\mathrm{Ni}$ was less than 1 , while $\mathrm{Zn}, \mathrm{Pb}, \mathrm{Mn}, \mathrm{Co}, \mathrm{Cr}$, and $\mathrm{Cu}$, was higher than 1.

\section{REFERENCES}

Abdel-Shafy, H. and A. Raouf (2002). Water issue in Egypt: Resources, pollution and protection endeavors. CEJOEM, 8: 3-21.

Abebe, N, K. Endalkachew, M. Mastawesha and A. Gebermedihin (2012). Effect of biochar application on soil properties and nutrient uptake of lettuces (Lactuca sativa) grown in chromium polluted soils. J. Agric. Environ. Sci., 12 (3): 369-376.

Abou-Shady, A. (2016). Effect of separated cathode on the removal of dissolved organic carbon using anode oxidation, Fenton oxidation, and coagulation. Journal of Environmental Chemical Engineering, 4: 704-710.

Alghobar, M.A. and S. Suresha (2016). Effect of wastewater irrigation on growth and yield of rice crop and uptake and accumulation of nutrient and heavy metals in soil. Applied Ecology and Environmental Sciences, 4 (3): 53-60.

AWRG (2010). Directory of Agricultural Waste Recycling. Ministry of state for Environmental Affairs.

Beata, D.B. and E. Cyraniak (2014). Influence factors in soil-fertilizer accumulation of heavy metals in plants. World Scientific News, 3: 20-27.

Biljana, B., S. Trajče and K. Bačeva (2015). Bioavailability and bioaccumulation characterization of essential and heavy metals contents in $R$. acetosa, $S$. oleracea and $U$. dioica from copper polluted and referent areas. Journal of Environmental Health Science \& Engineering, 13 (2): 1-13.

Chan, K.Y., L.V. Zwieten, I. Meszaros, A. Downie and S. Joseph (2008). Using poultry litter biochars as soil amendments. Australian J. Soil Res., 46: 437-444. 
Ghorbani, N.R., N. Salehrastin and A. Moeini (2002). Heavy metals affect the microbial populations and their activities. Symposium N 54 at $17^{\text {th }}$ World Congress of Soil Science, Thailand, 2234: 1-11.

Hang, Z., Y. Wen-Tao, Z. Xin, L. Li, G. Jiao-Feng, W. Wen-Lei, Z. JiaLing, T. Tao, P. Pei-Qin and B. Liao (2016). Accumulation of heavy metals in vegetable species planted in contaminated soils and the health risk assessment. Int. J. Environ. Res. Public Health, 13 (289): $1-12$.

Jackson, M.L. (1973). In "Soil Chemical Analysis". Prentice Hall, England, UK.

Klute, A.A (1986). In "Methods of Soil Analysis". Part $12^{\text {nd }}$ edition. American Society of Agronomy. Inc. Publishes, Madison, Wisconsin, USA.

Lehmann, J., J.P. Da Silva Jr, C. Steiner, T. Nehls, W. Zech and B. Glaser (2003). Nutrient availability and leaching in an archaeological Anthrosol and a Ferralsol of the Central Amazon basin: fertilizer, manure and charcoal amendments. Plant and Soil, 249: 343-357.

Liang, B., J. Lehmann, D. Solomon, J. Kinyangi, J. Grossman, B. O'Nell, J.O. Skjemstad, J. Thies, F.J. Luizao, J. Petersen and E.G. Neves (2006). Black carbon increases cation exchange capacity in soils. Soil Sciences Society of America J., 70: 1719-1730.

Montanarella, L. and E. Lugato (2013). The application of biochar in the EU. Challenges and Opportunities in Agronomy, 3: 462-473.

Naz, A., K. Sardar, S. Muhammad, S.L. Khalid, S. Alam, S. Siddique, A. Toqeer and S. Miklas (2015). Toxicity and bioaccumulation of heavy metals in spinach (Spinacia oleracea) grown in a controlled environment. Int. J. Environ. Res. Public Health, 12: 7400-7416.

Nicholson, G. (1984). Methods of soil, plant and water analysis. N. Z. Forest Service. F. R. I. Bulletin, 70.

Olowoyo, J.O., E. van Heerden, J.L. Fischer and C. Baker (2010). Trace metals in soil and leaves of Jacaranda mimosi-folia in Tshwane area. South Africa Atmospheric Environment, 44: 1826-1830.

Page, A.L., R.H. Miller and D.R. Keeney (1982). In "Methods of Soil Analysis". Part 2: Chemical and Microbiological Properties. Second Edition. Agronomy J. 9: 2, Am. Soc. Agron. Inc., Soil Sci. Soc. Am. Inc. Pub. Madison, Wisconsin, USA.

Piper, C.S. (1950). In "Soil and Plant Analysis", Waite Agric. Res. Inst., Adelaide, S.A., Australia.

Ramadan, M.A.E. and S.M. Adam (2007). The effect of chicken manure and mineral fertilizers on distribution of heavy metals in soil and tomato organs. Australian Journal of Basic and Applied Sciences, 1 (3): 226-231.

Egyptian J. Desert Res., 66, No. 2, 327-350 (2016) 
Rashed, M., S.R. Awad, M.A. Salam and E. Smidt (1995). Monitoring of groundwater in Gabal El Asfar wastewater irrigated area (Greater Cairo), Water Science and Technology, 32:163-169.

Rondon, M.A., J. Lehmann, J. Ramirezand and M. Hurtado (2007). Biological nitrogen fixation by common beans (Phaseolus vulgaris L.) increases with bio-char additions. Biology and Fertility of Soils, 43: 699-708.

Singh, A. and M. Agrawal (2013). Reduction in metal toxicity by applying different soil amendments in agricultural field and its consequent effects on characteristics of radish plants (Raphanus sativus L.). J. Agr. Sci. Tech., 15: 1553-1564.

Solomon, D., J. Lehmann, J. Thies, T. Schafer, B. Liang, J. Kinyangi, E. Neves, J. Petersen, F. Luizo and J. Skjemstad (2007). Molecular signature and sources of biochemical recalcitrance of organic $\mathrm{C}$ in Amazonian dark earths. Geochimica et cosmochimica Acta, 71: 2285-2298.

Song, W. and M. Guo (2012). Quality variations of poultry litter biochar generated at different pyrolysis temperatures, J. Anal. Appl. Pyrolysis, 94: 138-145.

Ure, A.M. (1995). In "Methods of Analysis for Heavy Metals in Soils". Heavy Metals in Soils. (Alloway, B.J. Ed.). Blacke Academic and Professional, An Imprint of Chapman and Hall, Wester Cleddens Road, Bishopbriggs, Glasgow G64 2NZ, UK., p. 58-102.

Verheijen, F., S. Jeffery, A.C. Bastos, M. Van der Velde and I. Diafas (2010). Biochar Application to Soils - A critical Scientific Review of Effects on Soil Properties, Processes and Functions. EUR 24099 EN, Office for Official Publications of the European Communities, Luxembourg, $149 \mathrm{pp}$.

Yu-kui R., Z. Fu-suo and S. Jian-bo (2009). Effects of nitrogen fertilization on heavy metal content of corn grains. International Journal of Experimental Botany, 78: 101-104.

Zayed, A., S. Gowthaman and N. Terry (1998). Phytoaccumulation of trace elements by wetlands plants: Duckweed. J. Environ. Qual., 27: 715721.

Zhang, X., H. Wang, L. He, K. Lu, A.Sarmah, J. Li, N. Bolan, J. Pei and H. Huang (2013). Using biochar for remediation of soils contaminated with heavy metals and organic pollutants. Environ. Sci. Pollut. Res., 20: 8472-8483. 


\section{تأثير إضافة الفحم النباتي على خصائص التربة وإنتاجية نبات الجزر النامي في الأراضي الملوثئة}

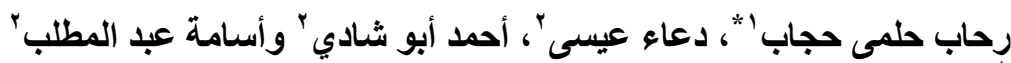

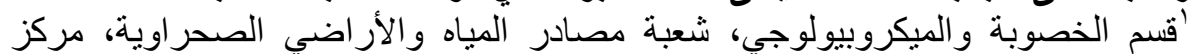

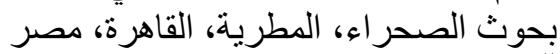

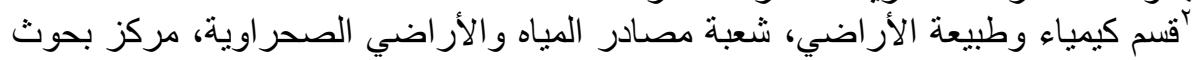

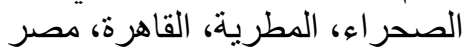

أصبح نلوث الأراضي بالفلزات الثقيلة واضحًا في كثير من المناطق المصرية مثل الجبل

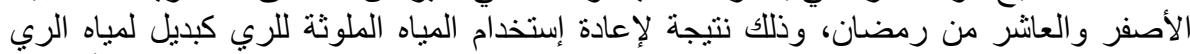

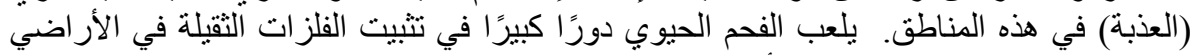

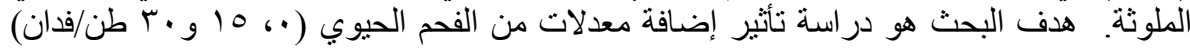

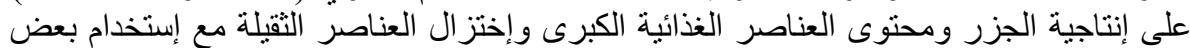

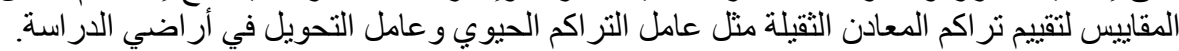

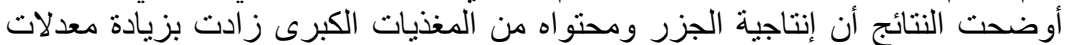

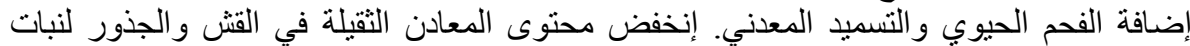

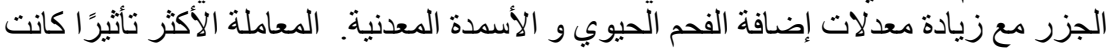
30 ton/feddan biochar with $41 \mathrm{~N}, 16.9 \mathrm{P}_{2} \mathrm{O}_{5}$ and $41.7 \mathrm{~K}_{2} \mathrm{O} \mathrm{kg}$ /feddan

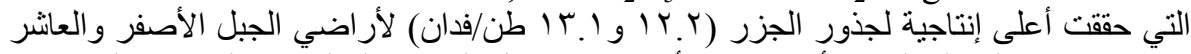

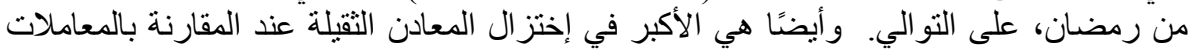

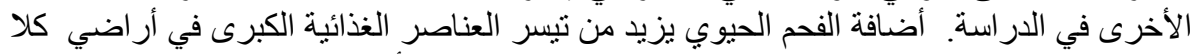

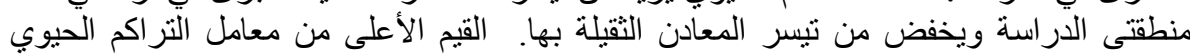

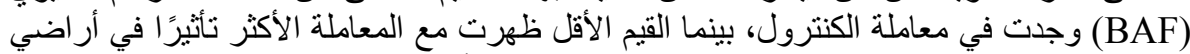

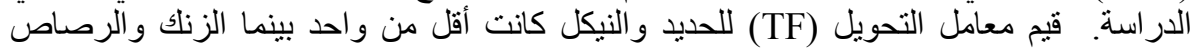
و المنجنيز و الكوبلت و الكروميوم والنحاس كانت أعلى من واحد. 